\title{
Research
}

\section{Anticipatory Learning for Climate Change Adaptation and Resilience}

\author{
Petra Tschakert $^{1,2}$ and $\underline{\text { Kathleen Ann Dietrich }}^{3}$
}

\begin{abstract}
This paper is a methodological contribution to emerging debates on the role of learning, particularly forward-looking (anticipatory) learning, as a key element for adaptation and resilience in the context of climate change. First, we describe two major challenges: understanding adaptation as a process and recognizing the inadequacy of existing learning tools, with a specific focus on high poverty contexts and complex livelihood-vulnerability risks. Then, the article examines learning processes from a dynamic systems perspective, comparing theoretical aspects and conceptual advances in resilience thinking and action research/learning (AR/AL). Particular attention is paid to learning loops (cycles), critical reflection, spaces for learning, and power. Finally, we outline a methodological framework to facilitate iterative learning processes and adaptive decision making in practice. We stress memory, monitoring of key drivers of change, scenario planning, and measuring anticipatory capacity as crucial ingredients. Our aim is to identify opportunities and obstacles for forward-looking learning processes at the intersection of climatic uncertainty and development challenges in Africa, with the overarching objective to enhance adaptation and resilient livelihood pathways, rather than learning by shock.
\end{abstract}

Key Words: Anticipatory capacity; action research/learning; climatic uncertainty; iterative learning; reflection; learning spaces; scenarios; development

\section{INTRODUCTION: CHALLENGES IN ADAPTATION RESEARCH AND PRACTICE}

Adaptation to the impacts of climatic changes is now at the forefront of scientific inquiry and policy negotiations. Yet, ongoing debates and interventions have contributed surprisingly little to the understanding of learning and decision-making processes that shape adaptation and resilient livelihoods, even beyond climatic risks. For instance, the widely cited paper on adaptation and adaptive capacity by Smit and Wandel (2006) contains no single reference to learning. We aim to fill this gap by offering a methodological contribution to current adaptation research and practice that is centered specifically on learning. With special emphasis on Africa, we begin by addressing two main challenges: grasping adaptation as a process and building adequate tools for anticipatory learning. We argue that, in the context of high and chronic poverty coupled with low awareness for complex drivers of change, these two challenges require particularly urgent attention and creative solutions.

\section{Understanding adaptation as a process}

The first major challenge in current adaptation work is to understand and demonstrate how adaptation functions as a process, and the wider implications of such a process for resilience. In many parts of Africa, the adaptation discourse is still predominantly focused on responding to the predicted impacts of future climate change rather than addressing the underlying factors that determine chronic poverty, vulnerability, and adaptive capacity - the ability to undertake adaptations or system changes. Policy and theory discourses have portrayed adaptation-adjustments to climatic changes, including moderating potential damage, taking advantage of opportunities, and coping with the consequences-as something that is orchestrated, if not imposed (Schipper 2007). The 
latest emphasis on "climate proofing" implicitly assumes that, once appropriate adaptation measures (typically technological in nature) are identified and implemented, development policies, plans, and practices can be shielded against adverse climate impacts (Brooks and Grist 2008). Such a project focus appears as a linear, largely self-limiting trajectory that favors readily identifiable and discrete adaptation actions, both anticipatory and reactive (before and after a shock), often presented in lists or inventories. More problematically, this view obscures the very processes that shape adaptation and resilient livelihoods.

Recent studies and project initiatives in some African and other developing countries, however, start to emphasize the process notion within adaptation. For instance, a synthesis of early adaptation projects in the Global South highlights the evolving nature of adaptation, including learning about risks, evaluating response options, and creating the right conditions for adaptive action (Leary et al. 2008). McGray et al. (2007) also stress the significance of decision making for adaptation efforts that evolve and improve with newly emerging conditions and information. They specifically refer to processes of "learning as we go," checking and rectifying possible maladaptation, exchanging information, and making trade-offs based on public values. Along the same lines, Osbahr (2007) views successful adaptation as a learned process in which appropriate communication channels constitute a crucial part. "The goal," as stated by T. Downing (unpublished manuscript), "is not to be well adapted but to adapt well."

Contrary to "hard" technological and infrastructural response options, this dynamic notion of adaptation promotes building resilience to enhance adaptive capacity now, rather than targeting adaptation in the future. Adaptive capacity, particularly from a systems perspective, has been described as the ability to learn from mistakes (Adger 2003), to generate experience of dealing with change (Berkes et al. 2003), and the capability for innovation (Armitage 2005). Fabricius et al. (2007) highlight learning, anticipating, and forecasting through knowledge sharing and responding. Under climate change, enhancing adaptive capacity implies paying explicit attention to learning about past, present, and future climate threats, accumulated memory of adaptive strategies, and anticipatory action to prepare for surprises and discontinuities in the climate systems (Nelson et al. 2007). The question that arises from these insights and debates is how to facilitate learning, information exchange, reflection, innovation, and anticipation, all of which are key elements in the practical reality of the adaptation process.

\section{Addressing the void in the existing learning toolbox}

This question brings us to the other and potentially more problematic challenge in adaptation research and practice: our existing methodological toolbox is sparsely equipped to facilitate and sustain such adaptive and anticipatory learning in the face of complex risks and uncertainties; in other words, learning about the future before impacts are apparent. Much progress has been made in the North, particularly in Europe and Canada, to design learning approaches, decision scenarios, and adaptation portfolios (Cohen et al. 2006, Kok et al. 2007, Jäger et al. 2008, Hulme et al. 2009) although it remains contested whether existing tools and models are sufficient for evaluating long time frames, cascading levels of uncertainty and surprises, and potentially catastrophic changes in the climate system (Tompkins et al. 2008). In contrast, in most parts of the Global South, but particularly in Africa (with the likely exception of South Africa), access to information, knowledge networks, and climate learning tools that build resilience into people's livelihoods, institutions, and ecosystems remain scarce, and especially so at the community level.

There are multiple reasons for this lacuna. From an international policy perspective, climate-related risks and vulnerabilities in drylands and other tropical ecosystems, many of which are in Africa, have received much less emphasis than colder areas, small island states, and indigenous communities portrayed as exceptionally unique and threatened (Liverman 2008). From the angle of science communication, research advances remain largely inaccessible to decision makers. Seely et al. (2008), with reference to southern Africa, assess the lack of integration and understanding of climate science into policy and practice, which hinders capacity building and decision making under uncertainty. Hellmuth et al. (2007:9), in a gap analysis on the use and application of climate information in Africa, point toward "inadequate supply of climate services ... for development decisions at all levels." As argued by Twomlow et al. (2008), even among 
African researchers and extension services, the understanding of climate processes, driving forces, and meaningful coping and adaptive strategies remains insufficient. Practitioners and communities encounter major obstacles to concrete adaptation planning; these include lack of awareness, knowledge, and access to forecasts in addition to sparse communication platforms and often unintelligible climate jargon (Enne and Yeroanni 2007, Leary et al. 2008).

Most worrisome is the absence of learning tools that explicitly encourage adaptation processes, including experimentation and innovation, in order to embrace complex risks and uncertainties. Although the Nairobi Work Programme, adopted under the UN Framework Convention on Climate Change in 2007, specifically emphasizes information, tools, and communication for adaptation planning and practice in developing countries, adaptive and anticipatory learning remains poorly understood. This is the case despite numerous researchers arguing for collaborative, iterative, self-organizing processes of learning-by-doing to enhance adaptive capacity and facilitate the role of boundary organizations for effective translation and diffusion (e.g., Füssel and Klein 2006, van Aalst et al. 2008). Such a gap is particularly problematic for countries where climatic uncertainties are high and impacts are likely to compound existing vulnerabilities with serious implications for development and poverty reduction.

\section{Learning challenges in the context of complex livelihood-vulnerability risks}

Our focus on Africa is deliberate as it is the continent where the "adaptation deficit" (Osbahr et al. 2007) - the lack of explicit integration of livelihood adaptation to climate change and broader development issues - has been most evident. In contrast to vulnerable and disadvantaged places and populations in the North as well as hazard-specific vulnerabilities to hurricanes, tsunamis, heat waves, and wildfires, Africa's vulnerability is tightly coupled with structural problems of chronic poverty, underdevelopment, food and livelihood insecurity, and socioeconomic and political inequality. The difference between the developing world and affluent countries lies in the magnitude and even more so the duration of poverty (Barrett and McPeak 2004). These distinct dimensions of day-to-day risks and structural poverty make the design of resilient livelihood pathways and the practicalities of adaptive capacity an exceedingly daunting task.

Conceptually and methodologically, the links between adaptation and (sustainable) development are well understood (Scoones 1998, Bebbington 1999, Mortimore and Adams 1999, Ellis 2000, McGray et al. 2007). Yet, as argued by Lemos et al. (2007), a more fruitful engagement between the two communities is needed to better build adaptive capacity under the unique risks and stresses related to climate change. Risk is seen here as "uncertain consequences, and in particular exposure to potentially unfavorable circumstances, or the possibility of incurring nontrivial loss" (Smith et al. 2000). People's ability to respond to risks is typically determined by a series of dynamic livelihood decisions that depend on the opportunity set of household asset endowments and the allocation of these assets to generate benefits and pursue a meaningful life (Davies 1996, Kelly and Adger 2000, Barrett et al. 2001, Little et al. 2001, Ellis 2003; Little et al., unpublished manuscript).

These complex livelihood-vulnerability contexts make novel experiments-crucial for successful adaptation and resilient pathways - a highly risky undertaking in which mistakes and failure may well mean a downward spiral from transitory to chronic poverty (persistent deprivation). As shown for pastoralist communities in eastern Africa, poor households, in a rational attempt to manage risk, often trap themselves in chronic poverty through the allocation of asset portfolios that are unproductive and insufficient to lift them beyond a critical poverty threshold (Barrett and McPeak 2004, Barrett 2010; Little et al., unpublished manuscript). Clearly, poverty dynamics, inequalities and power differentials, limits to adaptive strategies, and latent adaptive capacity all shape adaptation processes and options (Osbahr 2007). Our attempt to explore spaces for anticipatory learning is situated within these complex vulnerability-livelihood risks and interactions embedded within a wider development context.

We propose a methodological approach that emphasizes a multi-faceted, iterative way of analyzing and learning about changes and uncertainties to manage for resilience rather than learning by shock. Viewing adaptation as a socioinstitutional process that involves cycles of anticipation and responses to a variety of stressors 
is radically different from considering adaptation as an adjustment to predicted future climatic impacts or residual damage associated with these impacts. By focusing explicitly on learning, reflection, and forward-looking decision making about feasible, sustainable, and fair adaptation choices under various possible future climate realities, we portray vulnerable populations in Africa as active agents of change with particular skills, knowledges, and visions, rather than passive victims.

\section{LEARNING PROCESSES TO MANAGE FOR RESILIENCE: FROM THEORY TO PRACTICE}

Forward-looking learning and decision-support tools in the face of climatic and other complex changes that involve high uncertainty are needed more than ever. The challenge is to assess how and when people learn to manage change, absorb shocks, take advantage of new opportunities, adjust, or completely alter their lives and livelihoods. This section examines two theoretical frameworksresilience thinking and action research/learning (AR/AL) - to tease out key learning elements from a dynamic systems perspective that may bolster adaptation as a process. The end of the section examines the role of critical reflection, learning spaces, and power.

The rationale for this comparison is threefold: (a) There is an urgent need to bring together resilience and development theories (including action theory) and their mutual concerns for self-organization, buffering against shocks, and enhancing adaptive capacity to better inform practice and more explicitly take into account issues of equity and power (Osbahr et al. 2007). (b) Although resilience thinking and AR/AL have substantially built off each other, similarities with respect to learning processes have never been consciously made explicit. Our aim is to explore interesting parallels by illustrating when and how cyclical (loop) learning occurs. (c) Given the urgency and the scale of the problematic of managing for resilience under climatic uncertainty, particularly among the poor, we draw upon key facets of iterative learning and reflection that may facilitate anticipation and experimentation in practice.

\section{Learning within the resilience framework}

The capacity for learning and experimentation has long been understood as an integral part of resilience thinking. For instance, Davidson-Hunt and Berkes (2003) stress learning to live with change and uncertainty and combining different types of knowledge as two key principles for building adaptive capacity in social-ecological systems. A resilience perspective on adaptation emphasizes learning, self-organization, and flexibility as crucial ingredients for navigating complex feedbacks, thresholds, and system changes (Berkes et al. 2003). Social-ecological resilience, also in the context of climate change, highlights innovation and the capacity to learn and transform (Folke 2006). We focus on learning processes with special reference to adaptive cycles and managing for resilience.

Much of the current understanding of resilience and the embedded conception of learning expands on Holling's $(1973,1986)$ original notion of the term, which focuses on the maintenance of structure and functioning of complex systems that undergo disturbance. In his heuristic model of complex adaptive cycles, Holling (1986, 2004) suggests distinct types of learning: incremental front-loop learning, spasmodic or profound back-loop learning, and transformational learning that can lead to innovative processes with high potential for transformability. Within nested cross-level and cross-scale system dynamics where transformations happen, often unpredictably and abruptly (Gunderson and Holling 2002), learning can essentially take on two forms: (1) small and fast cycles "revolt" and affect larger and slower cycles; an example is successful local innovations that create opportunities for change at regional or international levels; (2) larger and slower cycles, through system "memory," shape dynamics at other scales by drawing upon accumulated knowledge and potential for renewal or reorganization (Fig. 1).

Recently, learning has been a prominent component in discussions on managing for resilience. This notion builds on Walker et al.'s (2002) idea of resilience management in which the main intent is to prevent social-ecological systems from sliding into undesirable states. Learning, memory, creativity, and the need to move forward in spite of imperfect knowledge and vast uncertainties are imperative to avoid unfavorable thresholds. Today's notion of managing for resilience entails both building and eroding resilience, the latter in the 
Fig. 1. Nested adaptive cycles (Folke 2006, after Gunderson and Holling 2002)

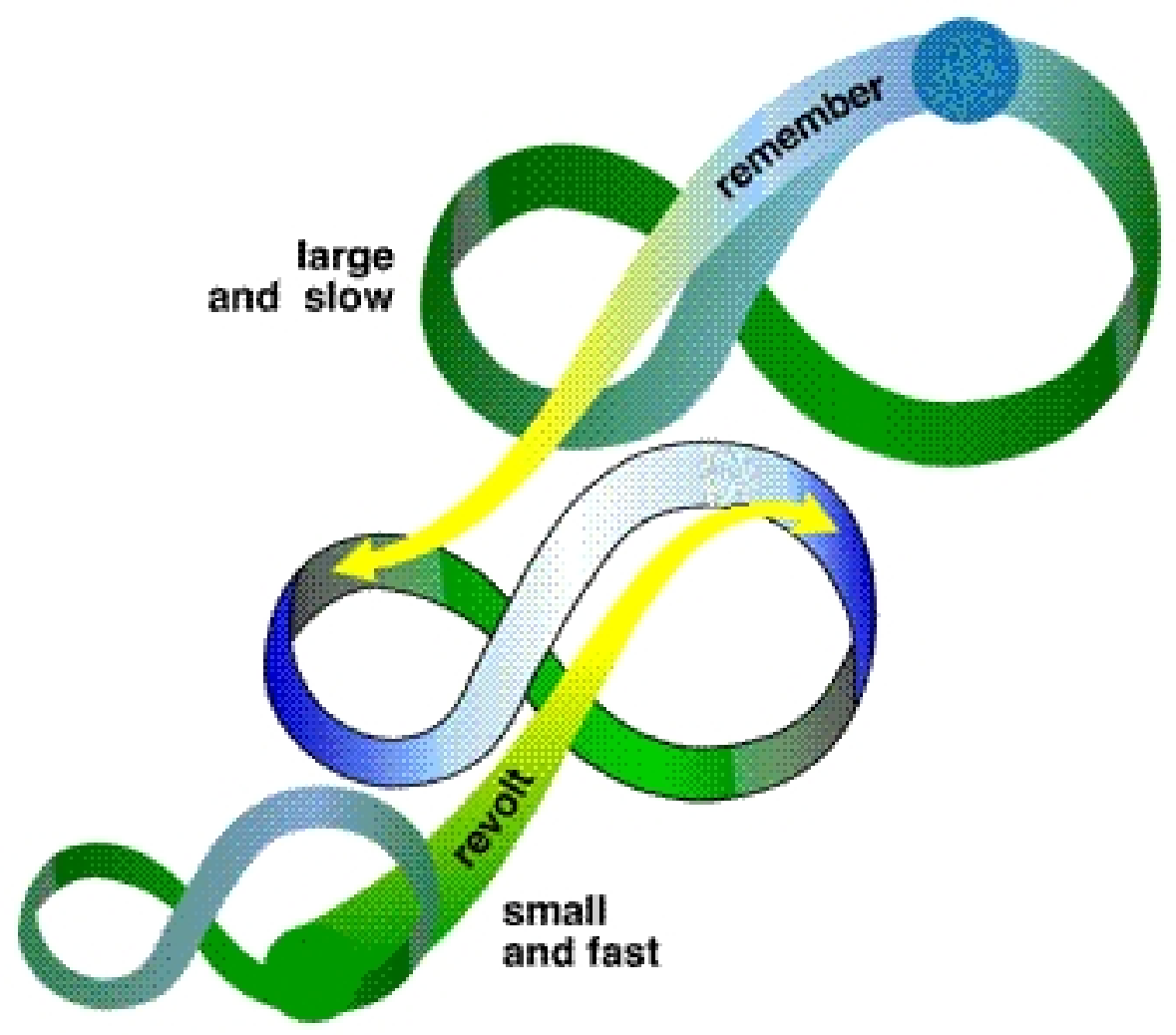

case of adverse system configurations (Lebel et al. 2006). Learning to cope with non-linearities and other types of uncertainties and surprises as well as flexible experiments for innovation are seen as key elements in this process. Most importantly, learning and the willingness to experiment play a central role for system transformation. Olsson et al. (2006) describe transformative capacity as the ability to create a radically new system when adaptation and adjustments are no longer possible or desirable and the existing system becomes untenable. To prepare for change, take advantage of windows of opportunity, and successfully navigate transitions, social actors ought to be aware of a problem, build knowledge, diversify their ideas, reflect, communicate, develop a shared vision, and act.

Albeit methodologically intriguing, managing for resilience under climatic uncertainties and in high poverty contexts is by no means a straightforward exercise. It involves fundamental methodological and ethical decisions such as: Managing resilience for whom? When to change from adaptation to transformation? How to shift from post hoc analyses to anticipatory thinking? Is continuing building adaptive capacity in low-income/high-vulnerability environments a waste of time? Despite these challenges, a resilience lens highlights learning as part of dynamic and flexible capacities that are critical when dealing with irreducible uncertainties. It allows a glimpse into how anticipation for climate change adaptation may shape resilient livelihood pathways in practice. The next section provides useful input from action research and learning. 


\section{Anticipatory learning within (participatory) action research and action learning}

Anticipatory or forward-looking learning is the key pillar of an approach known as anticipatory action learning (AAL), which falls under the larger umbrella of action learning (AL), a field of inquiry and practice that has converged with action research (AR) and future studies (Ramos 2006a). It is a collaborative, democratic, and heuristic-reflexive process that links iterative questioning, anticipation, learning, and creation with the ultimate purpose of crafting a different world (Stevenson 2002, Inayatullah 2002, 2006, Ramos 2006a). Kelleher (2005:85, 87) describes AAL as a "process of cocreating the future" based on a "theory of participative human agency." As core values, she stresses questioning of assumptions through reflection, creativity, systems thinking, and emergence of novel patterns through selforganization. Anticipatory action learning constitutes a process of foresight that is inherently diachronous; the outcomes emerge during the practice and are negotiated by those who participate, resulting in futures that are constantly revisited through envisioning, backcasting, experimenting, and reflection (Stevenson 2002, 2006, Ramos 2006b). As AAL does not subscribe to any particular (critical) theory, we review its main theoretical and methodological origins and underpinnings, with particular attention to action research.

Although AL has its roots in organizational learning and leadership development going back to Reginald Revans in the 1940s, AR - including participatory action research-stems from largely academic and development circles. It traces its origin to Kurt Lewin's work in social psychology from the early 1900s. Later, AR gained ground as a critique of positivist research approaches in the social sciences and mirrored academic disenchantment with the lack of action and concrete answers to persistent social and environmental problems resulting from poststructuralist thought (Greenwood and Levin 1998, Pain 2003, Kindon 2005). Action research can be described as a theory of and an approach to learning with a well-defined set of principles or dimensions of inquiry, embedded in a "metamethodology" (Reason and Torbert 2001, Dick 2002). Grounded in a participatory worldview, it explores the interaction of power relations across multiple scales and with particular emphasis on representing or giving voice to the marginalized (Maguire 1987, Park et al. 1993, Greenwood and
Levin 1998, Reason and Bradbury 2001). Its aim is to further reciprocal and transformational learning that results in future-oriented practical action (McTaggert 1991, Chandler and Torbert 2003).

Although AR rejects restricting itself to one theoretical perspective (Reason and Bradbury 2001), "action science" is seen as a grounding theory/practice. The key distinguishing features or dimensions of action science, described by Friedman (2001) and Reason and Torbert (2001), drawing upon Argyris and Schön (1974, 1978), Heron (1992), and Torbert (1983, 1991), are the following five: (a) creation of communities of inquiry where "theories of/in practice" are built and tested for learning; (b) centrality of participation; (c) experiential grounding, through critical subjectivity, multiple ways of knowing, and territories of experience; (d) normative, analogical, and implementable theory that seeks surprise and conditions for change; and (e) creation of alternatives to the status quo through experimentation and transformation.

The quintessential characteristic of these strands of action and learning schools is their focus on iterative, cyclical learning. Iterative cycles of acting, reflecting, and determining "windows" for solving emergent questions allow researchers and participants alike to develop and test theories through action and facilitate learning about complex situations. There are numerous, partially overlapping manifestations of this cyclical type of learning. They include Lewin's (1946) series of spirals of steps in $\mathrm{AR}$, as well as various forms of single, double, and triple feedback and loop learning (e.g., Kolb and Fry 1975, Argyris and Schön 1974, 1978, 1996, Keen et al. 2005, List 2006, Armitage et al. 2008). Single-loop learning allows correcting errors or improving the outcomes in standard management practices, for instance with respect to cropping techniques. Double-loop learning, by contrast, enables actors to learn about learning and question the assumptions behind inquiry, which enables shifts in understanding and behavior, whereas triple-loop learning can trigger changes in underlying norms and governance structures. Iterative cycles of single-, double-, and triple-loop feedback also enhance the sophistication and effectiveness of the four AR territories (vision, strategy, action, and outcomes) as depicted in the space-time-voice dimensions of transformational science (Torbert 1983, 1991, Chandler and Torbert 2003) (Fig. 2). 
These theoretical and methodological dimensions of AR/AL stress two other key elements: the element of reflection and that of anticipation. Critical reflection constitutes the backbone of iterative (loop) learning. Kolb and Fry (1975), for instance, argue that possibilities for "double-loop learning" emerge through reflection on experiences (what works and why) (Fig. 3). Such transformational learning happens at decisive nodes of reflection as they are likely to trigger new loops of learning, critical engagement, and the willingness to take risks (Fig. 4). They embody possibilities for unexpected connections and surprise. The role of anticipation in this learning process is to focus explicitly on possible futures by giving meaning to images, trends, and memory that can be qualitatively envisioned, tested, and revisited (Inayatullah 2006).

\section{Loop learning in practice: learning spaces and power}

Numerous practical applications of loop learning processes exist that build upon resilience theory and AR/AL, with prominent examples in the field of adaptive (co-) management (e.g., Olsson et al. 2004, Lebel et al. 2005, Armitage et al. 2007). Berkes (2009), among others, stresses the role coproduction of knowledge, power sharing, joint problem solving, bridging organizations, and reflection play. The adaptive facet of comanagement is captured in the incremental and iterative learning-by-doing process where system understanding, action, and evaluation are updated and refined every time new information is available.

We identify some overlapping key elements of resilience theory and AR/AL, distill implications for learning, and indicate how they may apply to climate change adaptation in practice (Table 1). Several of these reflect recent lessons from adaptive management and adaptation under climate change, for instance in the European ADAM Project, highlighting the need for processes that connect inquiry with experimentation and reflection to overcome incomplete knowledge about driving forces and uncertainties (Lonsdale 2009a). Two main questions merit further attention: (a) how can spaces for learning be created?, and (b) how to deal with power inequalities?
Although AR/AL processes can build the capacity of participants to challenge the underlying causes of their marginalization and vulnerability through an iterative and collective process of actionreflection, the spatiality of these processes remains under-researched. In the context of climate change adaptation, Thomas and Twyman (2005:121) called for the "need to create space, and the right kind of space, and to facilitate appropriate innovative and creative adaptation." But what is the right kind of learning space that encourages anticipatory learning and how do we build it?

We argue that such spaces need to have both an abstract and a material dimension. Kesby (2005) views such learning spaces as arenas in which people assess their own knowledge and its limits, renegotiate behavior, and improve communication. Empowerment and positive transformations in people's lives require "temporary time-space arenas" (Kesby 2005:2055). Within these arenas, empowered agency - the ability to act and change reality - can be reproduced, sustained, and scaled up within everyday spaces to facilitate transformation, something Kesby (2005:2039) calls "rehearsing for reality." Yet, such rehearsal requires sufficient ontological depth (Inayatullah 2006) to challenge and transform social reality. In other words, it is not sufficient to introduce small-scale revolts, perturbations, and learning probes in one sub-loop of the system (Lynam et al. 2002, Karkkainen 2006) if they cannot be sustained to alter awareness and behavior at larger scales.

However, such arenas for iterative, anticipatory, and transformative learning and reflection are rarely neatly structured. They require high creativity and flexibility, adjustments by "muddling through," and spontaneous constellations of cooperation, particularly in weak, unstable, and messy institutional and political settings (Wollenberg et al. 2007). It may be through this "messy" approach, mediated by bridging/boundary organizations, that windows of opportunity for experimentation and action can be detected and utilized. Referring specifically to adaptation, Pelling and High (2005) advocate for the opening of informal spaces (places of "bounded instability" or shadow systems/networks) outside of but connected to formal institutions to allow for novelty to emerge out of free experimentation, learning, and reflection. 
Fig. 2. The span of research/practice with four territories of experience (Chandler and Torbert 2003).

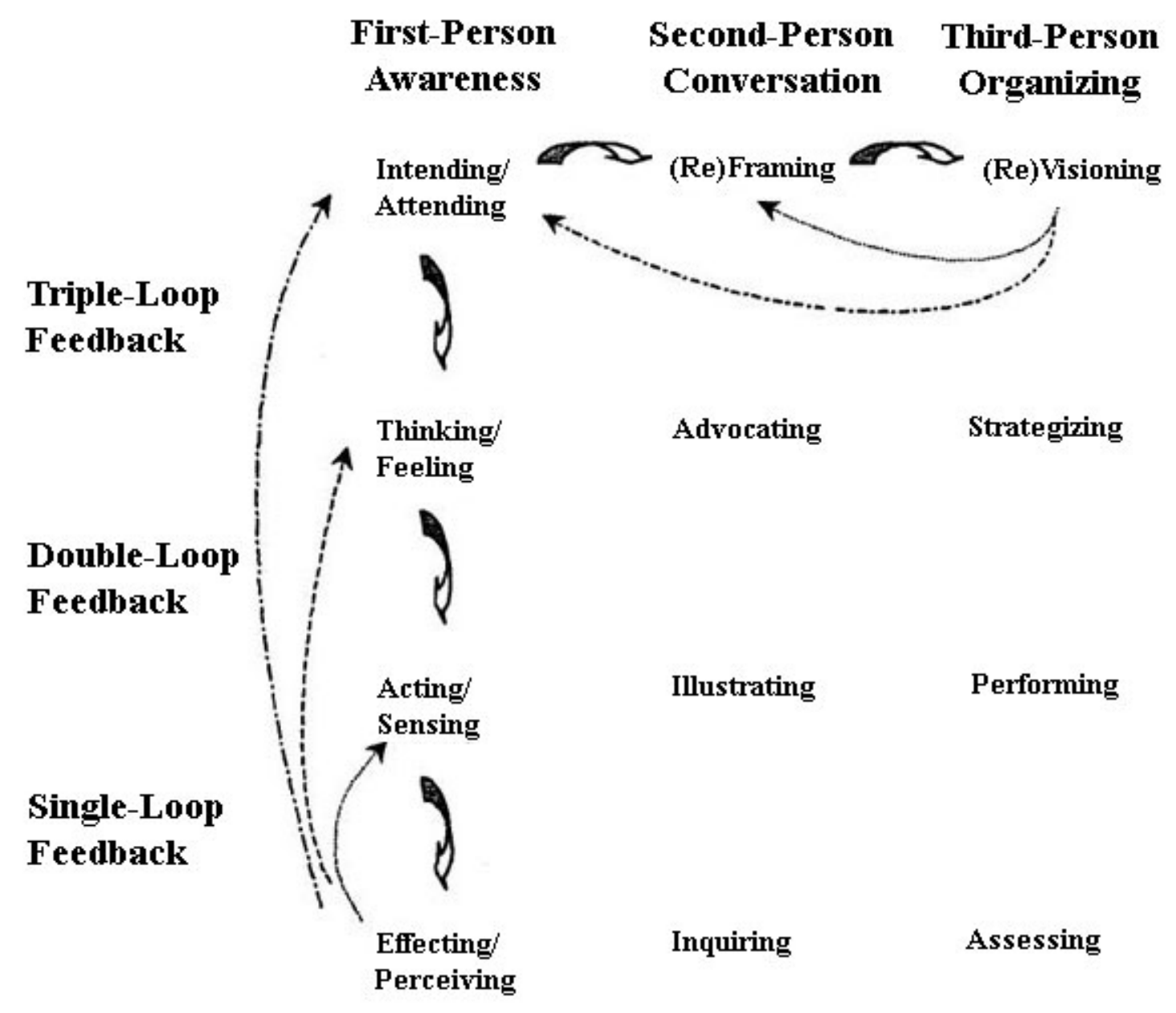

Finally, we do not want to suggest that such learning spaces are inherently harmonious. Much has been said about the "tyranny" of participation and participatory spaces of power and domination (e.g., Lefebvre 1991, Cooke and Kothari 2001). Yet, inequalities of power simply cannot be avoided. Acknowledging and negotiating power and conflicts need to be seen as integral parts of learning processes. This should not distract from the fact that not all participants in these time-space arenas may benefit equally. Osbahr (2007), for instance, describes adaptation and transformation of livelihood strategies as a competitive process that produces winners and losers. To engage with the deeply ethical question of who learns and who benefits, the typology of AR practices, as presented by Reason and Torbert (2001), seems particularly useful. First-person research allows the researcher to learn through self-reflexive action and critical subjectivity. Second-person research pursues cooperative inquiry and a consensus-seeking process for and with research partners. Third-person research strives for inquiry that involves wider learning communities through networks of organizations. In practice, it is through the integration of all three levels that learning and transformation are most likely to be achieved (Bradbury and Reason 2001). 
Fig. 3. Double-loop learning (Brockbank and McGill 1998).

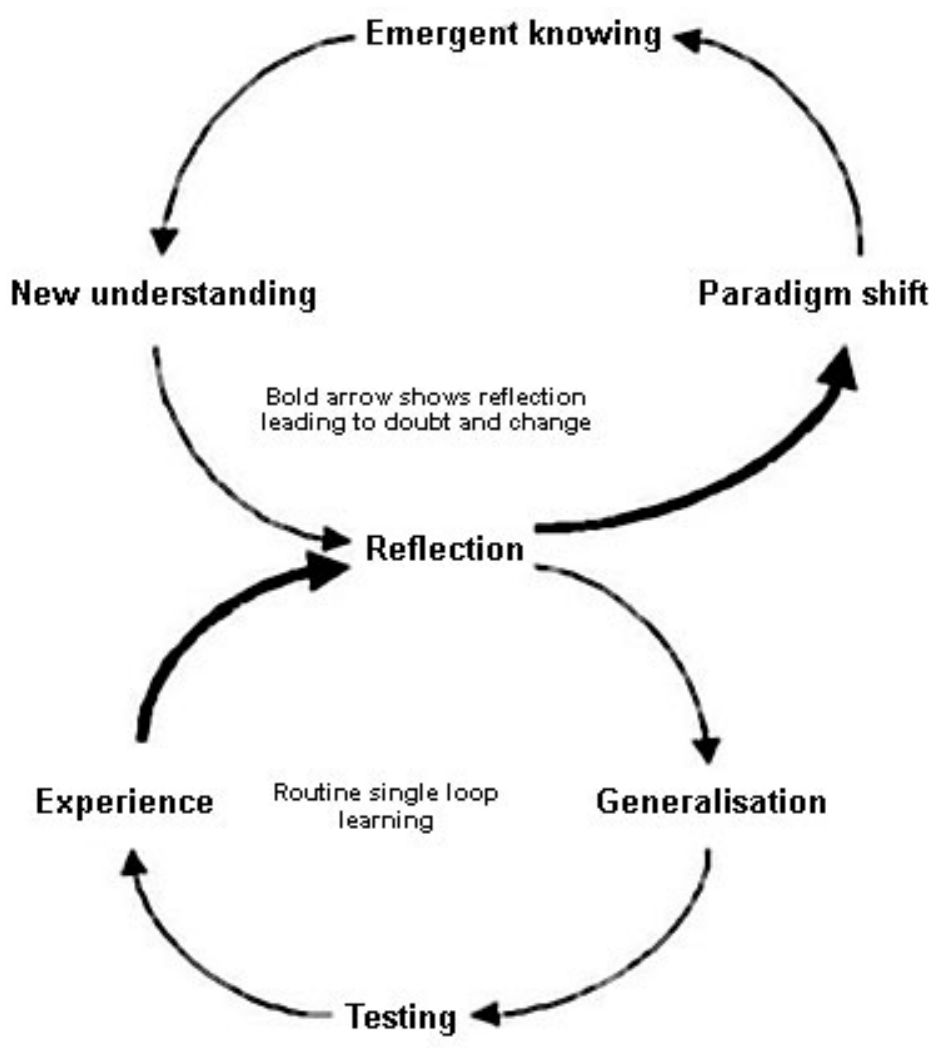

\section{ANTICIPATORY LEARNING AND MANAGING FOR RESILIENCE UNDER CLIMATE CHANGE: A METHODOLOGICAL FRAMEWORK}

Without testing in the real world, more concepts, tools, and methods and better science solutions will only be of academic interest unless these solutions make sense "on the ground" and can be absorbed and implemented (Lonsdale 2009b:2)

What is the relevance of comparing these theoretical and methodological insights from resilience thinking and AR/AL in the context of climatic changes? We argue that the most significant lesson is the recognition that the impetus for anticipatory and transformative learning stems from AR/AL's explicit emphasis on creating deliberative spaces for learning; these spaces then allow participants to challenge the very causes of their vulnerability through an iterative process of action-reflection (Fig. 5). Risks can be reduced, agency building enhanced, and resilient livelihood pathways designed through the iterative re-performance within time-space learning arenas. Participants can explore ways to achieve resilient designs in practice by moving forward despite imperfect knowledge, risks, and uncertainties and taking advantage of windows of opportunity. Through this learning process, they may be able to transform undesirable states-transitory and even chronic poverty and marginalization - into more desirable and resilient futures. Managing for resilience is hard work, not simply a twist of fate.

We propose the following methodological framework for facilitating anticipatory learning as an iterative socioinstitutional process, specifically for high poverty/high livelihood vulnerability contexts. We draw upon concrete examples from an 
Fig. 4. Nodes of reflection, triggering new learning loops in an ACM process for creating better livelihood options (Hartanto et al. 2003:64).

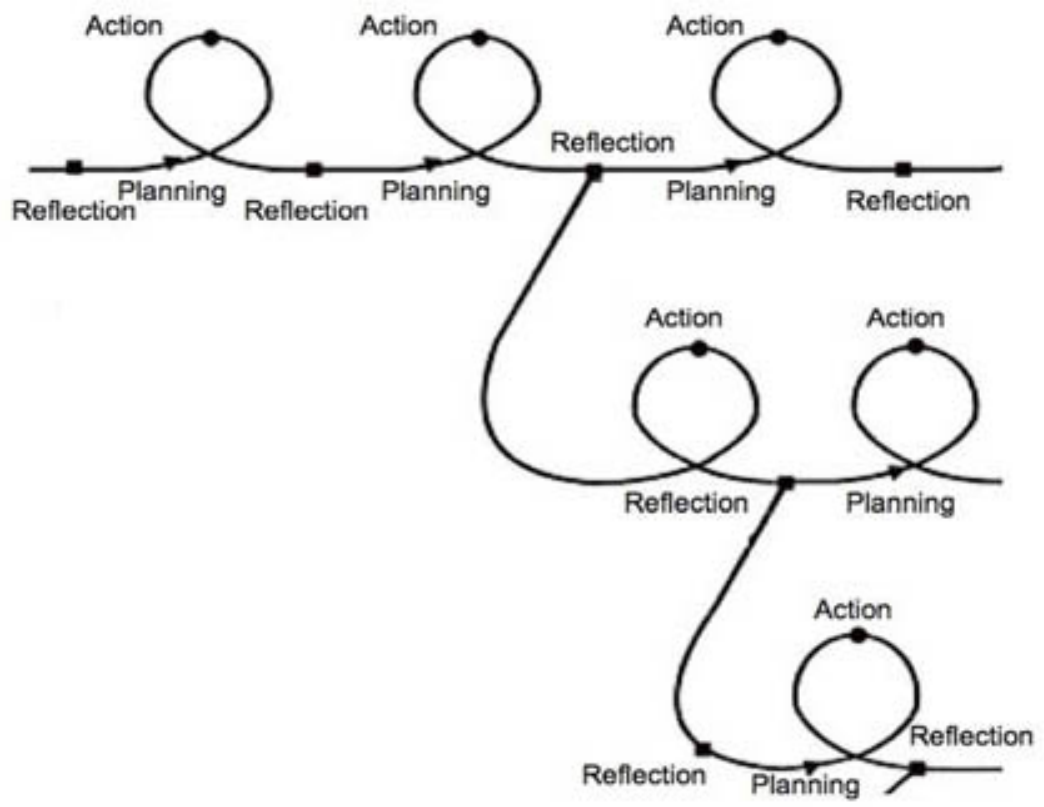

ongoing climate change project (CCLONG) in Ghana, a country where increased frequency and severity of extreme climate events result in impacts that are outside the usual and experienced coping range. The framework consists of five elements (Fig. 6): (1) lessons learned from the past (memory); (2) monitoring and analysis of trends to anticipate future events; (3) deliberate surprises, perturbations, and discontinuities that distinguish anticipated change from known (and potentially also cyclical) change; (4) measures of anticipatory capacity; and (5) design of decision-support tools for adaptation planning.

\section{Lessons learned from the past}

Both resilience theory and AL/AR pay attention to accumulated knowledge and stored or latent potentials for renewal and reorganization ("memory"). Memory, also referred to as "experiential grounding," serves as the knowledge base underlying the capacity for anticipating and envisioning future uncertainty and surprise. Consequences of past experiences and the emotions associated with them allow for learning that prevents the repetition of mistakes and opens future choices based on present decisions (Walker et al. 2006, Marx et al. 2007, Bohensky 2008). In practical terms, this involves an understanding of how people have responded to past climatic extremes (e.g., floods and droughts), what concrete decisions they have made in the face of slow and rapidly changing conditions, and what strategies were most and least effective and for whom.

It can be argued that people's memory is flimsy, especially if past experiences are quite dated. Also, lessons from the past may no longer be meaningful if contexts have changed (Bohensky and Lynam 2005). Yet, people who subsist in marginal environments, as in many parts of Africa, tend to have surprisingly good recollection of events and thresholds that may have pushed them into a poverty trap and attempts to get out of such lock-ins. Their memory, ability for self-organization, and agency are of particular importance for adaptation planning 
Table 1. Conceptual similarities and overlaps between the resilience framework and participatory action research/learning (AR/AL), implications for learning, and examples for climate change adaptation.

\begin{tabular}{|c|c|c|c|c|}
\hline $\begin{array}{l}\text { Resilience } \\
\text { Framework }\end{array}$ & $\begin{array}{l}\text { Action Research/ } \\
\text { Learning (AR/AL) }\end{array}$ & Implications for Learning & & $\begin{array}{c}\text { Examples for Climate Change } \\
\text { Adaptation }\end{array}$ \\
\hline $\begin{array}{l}\text { Complex adaptive } \\
\text { cycles }\end{array}$ & $\begin{array}{l}\text { Loop learning and } \\
\text { spirals of steps }\end{array}$ & $\begin{array}{l}\text { Iterative, cross-level/cross- } \\
\text { scale information exchange }\end{array}$ & $\rightarrow$ & $\begin{array}{l}\text { Learning about and practicing } \\
\text { adaptation as an action-reflection } \\
\text { process }\end{array}$ \\
\hline $\begin{array}{l}\text { Windows of } \\
\text { opportunities }\end{array}$ & Nodes of reflection & $\begin{array}{l}\text { Opening for unexpected } \\
\text { connections, innovation, and } \\
\text { transformation }\end{array}$ & $\rightarrow$ & $\begin{array}{l}\text { Possibility for adjustment in } \\
\text { agriculture or diversification out of } \\
\text { agriculture }\end{array}$ \\
\hline Memory & Experiential grounding & $\begin{array}{l}\text { Knowledge base for } \\
\text { envisioning the future }\end{array}$ & $\rightarrow$ & $\begin{array}{l}\text { Lessons learned from past } \\
\text { droughts and floods to facilitate } \\
\text { foresight }\end{array}$ \\
\hline Re-organization & $\begin{array}{l}\text { Insightful questioning } \\
\text { for action }\end{array}$ & $\begin{array}{l}\text { Challenging assumptions and } \\
\text { worldviews }\end{array}$ & $\rightarrow$ & $\begin{array}{l}\text { Understanding of local and global } \\
\text { drivers of climatic changes }\end{array}$ \\
\hline Experimentation & $\begin{array}{l}\text { Testing theories } \\
\text { through action/practice }\end{array}$ & $\begin{array}{c}\text { Flexible, incremental learning- } \\
\text { by-doing, learning from } \\
\text { mistakes }\end{array}$ & $\rightarrow$ & $\begin{array}{l}\text { Local monitoring of climate and } \\
\text { other changes and testing } \\
\text { adaptation options }\end{array}$ \\
\hline Back-loop learning & $\begin{array}{l}\text { Co-production of } \\
\text { knowledge and } \\
\text { multiple voices }\end{array}$ & $\begin{array}{l}\text { Arena for creative knowledge } \\
\text { generation }\end{array}$ & $\rightarrow$ & $\begin{array}{l}\text { Local and scientific climate } \\
\text { knowledge and re-abstraction of } \\
\text { external information }\end{array}$ \\
\hline Self-organization & $\begin{array}{c}\text { Spontaneous } \\
\text { cooperation and } \\
\text { bounded instability }\end{array}$ & $\begin{array}{c}\text { Participant-led problem solving } \\
\text { and action }\end{array}$ & $\rightarrow$ & $\begin{array}{l}\text { Agricultural innovation through } \\
\text { farmer-extension agent } \\
\text { collaboration }\end{array}$ \\
\hline Revolting & $\begin{array}{l}\text { Challenging of power } \\
\text { imbalances }\end{array}$ & $\begin{array}{l}\text { Empowerment, new dynamics } \\
\text { across scales }\end{array}$ & $\rightarrow$ & $\begin{array}{l}\text { Shift from vulnerable people as } \\
\text { passive victims of climate change } \\
\text { to active agents who shape change }\end{array}$ \\
\hline $\begin{array}{l}\text { Small disturbances } \\
\text { and surprises }\end{array}$ & Management probes & $\begin{array}{l}\text { Out-of-the box thinking, } \\
\text { innovative learning }\end{array}$ & $\rightarrow$ & $\begin{array}{l}\text { Introduction of extreme climate } \\
\text { events into scenario building to } \\
\text { explore adaptation options } \\
\text { exceeding current response } \\
\text { repertoire }\end{array}$ \\
\hline $\begin{array}{l}\text { Navigating } \\
\text { transitions }\end{array}$ & Rehearsing for reality & $\begin{array}{l}\text { Learning spaces for } \\
\text { transformation }\end{array}$ & $\rightarrow$ & $\begin{array}{l}\text { Several alternative plans for } \\
\text { managing climate uncertainties }\end{array}$ \\
\hline
\end{tabular}

(Twomlow et al. 2008). Methods used under the CCLONG project for investigating memory include historical matrices on extreme events, listing, ranking, and scoring of response strategies, and mapping of knowledge transfer within and between communities during times of crisis. Other studies confirm that shared knowledge and experiences from past climate events can raise awareness, spur resourcefulness, and provide a sense of agency among the poor to feel prepared for future climate shocks (Finan and Nelson 2001, Tschakert 2007, Nelson and Finan 2008). 
Fig. 5. Elements of a deliberative learning space for building anticipatory capacity.

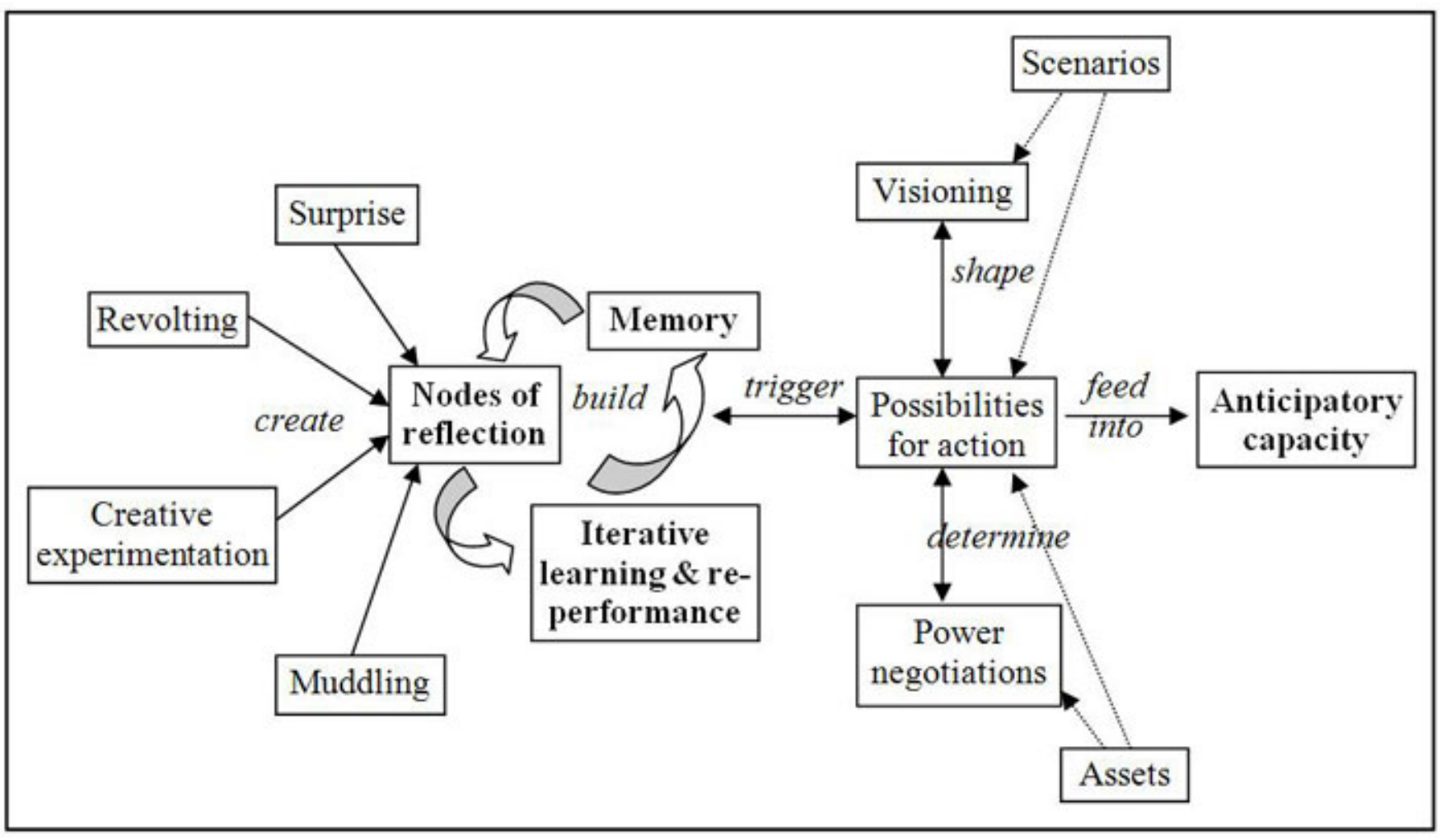

\section{Monitoring and analysis of trends to anticipate future events}

Although past and present actions inform reorganization, the system is still constrained by the consequences of past response, larger and slower variables (cycles) or drivers of change, and insufficient knowledge (Walker et al. 2006, Marx et al. 2007, Bohensky 2008). Thus, identifying and monitoring slowly changing variables such as rainfall patterns and integrating and reflecting on new knowledge allows for a better understanding of processes that are already under way. The same is true for anticipating possible events assuming observed trends continue. Monitoring enhances flexibility during times of disturbance and boosts the capacity for anticipatory action.

Bohensky and Lynam (2005) and Bohensky (2008), analyzing water management in southern Africa, stress awareness of impacts as well as drivers of change as key elements in learning and constructing effective response options. Drivers of change may include external shocks and surprises such as climatic changes, people's hopes and fears for the future, and actions of policy makers, for instance imposed policies (Walker et al. 2002). In a context of high livelihood risks and vulnerabilities, many of which are likely to be further exacerbated by climate change, it is particularly crucial to thoroughly monitor ecological and socioinstitutional processes. The failure to do so may result in outdated and potentially counterproductive adaptation policies, projects, and strategies, even before they are implemented (Enfors et al. 2008).

Experiences in the CCLONG project have shown that drivers of climate change remain poorly understood, especially global drivers outside of people's empirical radar. True, the uncertainties of climate variations are fairly abstract concepts that necessitate analytic understanding and, therefore, often the introduction of external information such as historic meteorological records and climate 
Fig. 6. Methodological framework depicting anticipatory learning for climate change adaptation with embedded cycles of critical reflection, anticipation, and responses.

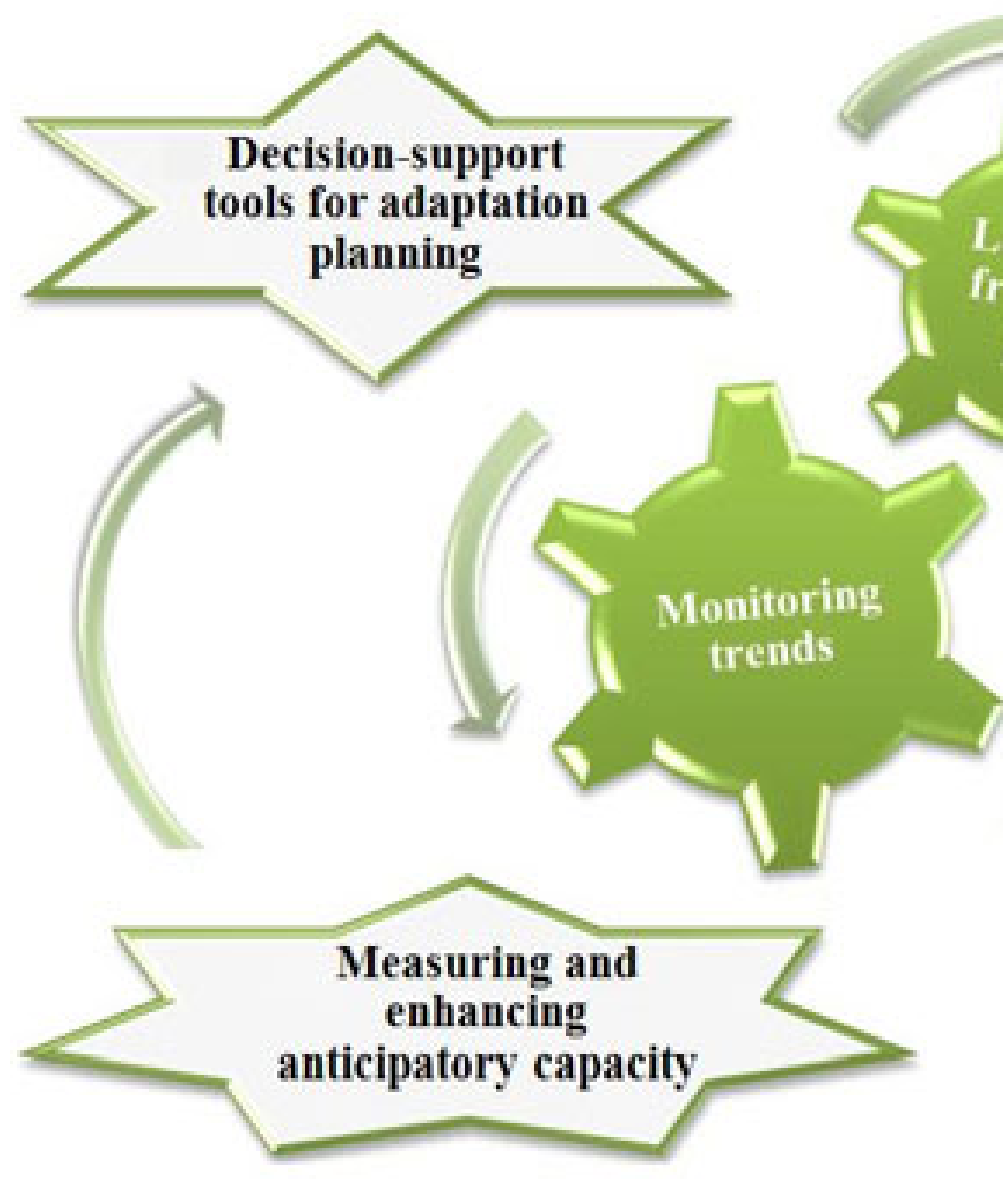

projections (Marx et al. 2007, van Aalst et al. 2008). These can raise awareness, fill potential knowledge gaps, and initiate reflection on the efficiency of current adaptation strategies under possible future conditions. Although caution is required when adding science information to the learning process (van Aalst et al. 2008), co-generating knowledge between researchers and stakeholders allows for the re-abstraction of analytical information into changes in memory and action. Even if subsistence farmers have no control over most larger-scale driving forces (such as emissions from cars and industries in the North), a better understanding of the mechanisms behind these drivers can enhance confidence in anticipating change (Biggs et al. 2007).
In Ghana, we have distributed simple rain gauges to record precipitation events and initiated community-based monitoring systems for expected timing, duration, and severity of looming heavy rains and dry spells. For instance, overabundance of small black ants in homes and farm plots suggest heavy rains and flooding will occur. Such local monitoring is combined with community fora to address certain misconceptions of climate change. Most recently, CCLONG hosted open days in two district capitals to complement existing knowledge with a more detailed science perspective and engage the diverse audiences (150-190 people) into discussions on greenhouse gases, the ozone hole, historical climate data and trends, seasonal forecasts, and downscaled climate projections for 
2065. Now, high schools request similar information events.

\section{Planning for surprises, perturbations, and discontinuities through scenarios}

The third part of the framework moves from memory and relatively predictable trends to surprises, discontinuities, and potentially cataclysmic events. As stated by Scoones, the "real world" is shaped by "ignorance and surprise," not just risks (Osbahr et al. 2007:16). The capacity to cope with nonlinearities and other surprises depends largely on openness for learning, the willingness to accept change as inevitable, and the ability to engage in interventions/experiments (Lebel et al. 2005). Processes of inquiry, experimentation, and reflection are essential given incomplete knowledge about climate change (van Aalst et al. 2008, Lonsdale 2009a). Hence, we advocate for the use of participatory scenario planning/building as a methodological tool not only to explore interconnectedness, surprises, and uncertainties but also to offer empowering learning spaces where multiple voices, experiences, and constraints can be heard. Echoing AR/AL, we see it as an "exercise of agency" (Ramos 2006b).

Scenarios are stories of plausible futures and the ways they may unfold. Scenario building is a participatory process that involves multiple stakeholders and their creative visions for assessing situations in which future-shaping factors are uncertain and often impossible to control (Wollenberg et al. 2000, Swart et al. 2004, Evans et al. 2006, Biggs et al. 2007, Peterson 2007). Uncertainties may include climatic ones as well as daily life and livelihood stressors and larger-level economic, environmental, and policy disturbances and risks. They are best investigated through alternative storylines and different iterations (cycles), each focusing on subsets of driving forces of change. Learning and innovative thinking are expected to occur by exploring what is not known, often through the use of management or learning probes (envisioning a disturbance that exceeds actual experiences, for instance drought and flooding back to back), deliberating scenario outcomes, anticipating consequences, and planning adaptive responses. Hence, scenario building exemplifies communities of inquiry where "theories of/in practice" are built and tested for opening "windows of opportunity" and preparing for transformation.
Scenario building is now recognized as a useful tool to examine climate risks and uncertainties and involve decision makers in the adaptation process. Several integrated assessment projects in Europe, including VISIONS, MedAction, and ADAM, have used scenario building to explore the impacts of climate change across multiple scales (Kok et al. 2003, Biggs et al. 2007, Patel et al. 2007). In Africa, scenario building focuses mainly on managing natural resources and ecosystem services (Lynam et al. 2002, Bohensky and Lynam 2005, Ochola et al. 2006, Kok et al. 2007, Bohensky 2008, Enfors et al. 2008). In fact, Biggs et al. (2007) caution that incorporating global issues such as climate change into local-scale scenarios may hijack community concerns, which could result in loss of credibility and ownership over the process. Although we see the danger, we argue that there is an enormous need to tackle local-level climate change for adaptation planning; scenario building provides an ideal space for exploring options, uncertainties, limitations, and trade-offs. Rather than imposing climate change as a "foreign" element into one single scenariobuilding exercise, we believe that fruitful learning outcomes stem from iterative experiences and cycles of reflection. Empowered agency and managing for resilience can be sustained through the continuity of the learning process before and after the scenario building.

For complex livelihood-vulnerability contexts, drawing upon Biggs et al. (2007), we propose localscale exploratory scenarios that are loosely linked to larger-scale drivers. Typical elements in cocreated storylines include local and regional environmental change and development trajectories coupled with actual manifestations of poverty. We also advocate for integrating down-scaled climate projections. This differs from other scenario exercises in Africa that use long-term projections or general descriptors of possible climatic changes (Ochola et al. 2006, Enfors et al. 2008). Our experiences in the CCLONG project show that local resource users, teachers, agricultural extension agents, and policy makers are all interested in more detailed projections. For example, the available data for central Ghana indicate more delays in the onset of the rainy season, an increased likelihood of more frequent and more severe dry spells in the middle of the major season (June-July), and risks of more heavy rainfall events toward the end of the season. It is crucial that this external science information is introduced and re-abstracted in prior learning cycles and then reused through the storylines and experimented with as management probes that 
exceed current adaptation repertoires. To make alternative scenarios more plausible, facilitate ownership over the stories and the characters involved, and strengthen second- and third-person research/practice, we use visual representations through local artists and participatory environmental theatre and video (see also Biggs et al. 2007, Enfors et al. 2008).

\section{Measures of anticipatory capacity}

The fourth component in our methodological learning framework is the most challenging as it attempts to identify and measure people's capacity for anticipation. With several learning cycles of remembering, monitoring, re-abstracting knowledge, and exploring uncertainties and surprises through experimentation and reflection, possibilities for action should emerge that then feed into anticipatory capacity (see Fig. 5). We define this capacity as the ability to shift from envisioning possible futures (as explored through scenario planning) to the ability to develop a dynamic plan for how to deal with potential uncertainties. In AAL, this is understood as the capacity to "see what is not commonly seen and create what is not commonly known" (Inayatullah 2006:656). Stevenson (2006) argues that people make the transition from vision to action through the integration of critical reflection into a decision-action "process of foresight." This is similar to preparing for system change in resilience thinking.

In the context of high poverty/high vulnerability, the crucial ingredient for grasping windows of opportunity and actively shaping change in this transition is empowerment. According to Bohensky and Lyman (2005), effective strategies are chosen and implemented at the congruence of being aware of the scope and drivers of a certain impact and feeling empowered to respond to it. As witnessed in the CCLONG project, rural stakeholders feel overwhelmingly powerless to alter the larger-scale processes that influence these changes. Often, they refer to Allah or God as holding the supreme power to determine rains and periods of drought. Having access to learning spaces where existing assumptions can be questioned and alternative pathways tested and reflected upon makes today's realities and future uncertainties less terrifying.

In order to measure such anticipatory capacity, we need to first understand where it resides. Although social actors can certainly enhance their individual forward-looking abilities, we argue that anticipatory capacity emerges and flourishes at the intersection of first-person awareness, second-person conversation, and third-person organization, as depicted by Chandler and Torbert (2003); see Fig. 2). Inspired by Alexander Ballard Ltd. (2008), we propose the following broad determinants of individual and collective anticipatory capacity for a developing country context: awareness of climate change, experiences with and effective responses to past climatic extremes ("memory"), agency, leadership, engagement in concrete learning activities with external agents (researchers), collaboration, availability of wider communication networks and access to climate information, visionary yet tangible planning outcomes for dealing with future conditions through consensus building (scenarios), and managing change.

Given the collaborative nature of anticipatory learning processes, it seems essential to encourage all participants, from community members to researchers and policy makers, to design their own metrics for success. This substantially reduces the danger of being hijacked by external agendas. The only requirement is that these metrics and tools for evaluation are based on clearly defined objectives and desired outcomes at the very beginning of the first learning loop and continually rehearsed. Practically, we can measure variables such as evolving awareness of climate and other changes, the willingness and ability to engage with unknown yet conceivable risks, and channels for information exchange through methods such as individual and community learning baselines and network mapping. More challenging is to pinpoint specific nodes of reflection at particular constellations in time and to evaluate-in retrospect and in anticipation-emerging pathways, the factors that make some pathways more resilient than others, and the ultimate choices people make. This is a start; yet, we realize that other variables or proxies for anticipatory capacity may exist and deserve further exploration.

\section{Design of dynamic decision-support tools for adaptation planning}

To date, few cyclical learning and decision-support tools exist to explore anticipatory adaptation in high poverty/high vulnerability contexts. Interactive, multi-media learning tools in developed countries, 
including the "Winds of Change" board game from the European Climate Forum and Potsdam Institute for Climate Impact Research, the Australian TV show "Scorched," and the UK Climate Impacts Programme's Adaptation Wizard, serve as inspiration for creative approaches that involve the public in climate change debates. The irony is that places and populations that have low levels of adaptive capacity and would need such empowering tools most are the last to be served. International non-government organizations, such as the International Red Cross and Red Crescent and CARE International, are beginning to embrace the possibility of using their community-based decision risk reduction and development tools to facilitate more active, engaged, and forward-looking learning (e.g., Red Cross/Red Crescent 2007). However, caution is required to capture the unique intersection of slow and rapidly changing climate conditions with complex livelihood vulnerabilities. Integrating climate change information into AAL processes calls for a skillful blend of a potentially top-down external agenda with local-level awareness and agency building. We have only started to investigate possible options.

\section{CONCLUDING THOUGHTS: OPPORTUNITIES AND CHALLENGES}

We have shown that both resilience thinking and AR/AL have vital contributions to make for anticipatory learning in the process of climate change adaptation. However, so far, these contributions have occurred in parallel rather than synergistic ways, and we argue that the time is ripe to integrate these two schools of thought and practice much more effectively. Boyd (Osbahr et al. 2007) is right in noticing that issues of power, agency, and equity in social systems have yet to be explicitly incorporated into resilience thinking. At the same time, the adaptation and development community has lots to learn from resilience management by navigating periods of transformations in high poverty and high vulnerability contexts.

An important opportunity to achieve this integration occurs by creating learning spaces to build adaptive and anticipatory capacity with and for vulnerable populations, and to appreciate what adaptation options may be most feasible, sustainable, and fair under possible future climate and development realities. We have described learning spaces as arenas of iterative, experiential learning-by-doing processes of action-reflection in which underlying causes of vulnerability can be challenged and alternative behavior, visions, and trade-offs renegotiated and re-performed. Although such learning spaces are a refreshing and long overdue complement to, if not substitute for, infrastructural adaptation projects, there is no doubt that they can be appropriated by power dynamics. Naming, acknowledging, and actively engaging with power differentials implies recognizing learning outcomes - in this case concrete adaptive responses-as a competitive process shaped by hierarchical and political control (Stevenson 2006, Osbahr 2007). Despite the participatory, democratic, and pluralistic underpinnings that typify anticipatory action learning, not everybody is able to afford participation and some will benefit much more than others.

We have presented a methodological framework built around five elements for facilitating anticipatory learning processes as well as some practical examples of how to implement it. Although the individual elements are by no means new, we believe the iterative and cyclical structure in this reflection-decision-action process of foresight enables poor and vulnerable communities to transform their current conditions into more desirable and resilient futures. The process highlights their rights and skills to reduce harm and avoid undesirable thresholds by providing space for their framings and imaginations. Yet, the real challenge remains "on the ground." Carr (2008) questions the fairness, durability, and gender implications of seemingly successful local adaptations. Others point to new anxieties among "the vulnerable" that may be triggered by learning about climate complexities and uncertainties (van Aalst et al. 2008). Leary et al. (2008) draw attention to unexpected inability or lack of will to participate and adapt.

Most of these obstacles need to be seen in light of multifaceted livelihood-vulnerability risks that distinguish African contexts from those in the North. Equally to blame are inadequate communication channels to connect with deprived populations and insufficient protection against risks and failures that are likely to result from innovative experiments. Although agency building and empowering learning spaces can help identify and spread risks, it is largely the responsibility of state and non-governmental agencies to remedy structural poverty and limited asset portfolios. This 
includes providing "safety nets" to help the transitory poor over rough patches and more substantial "cargo nets" to boost asset productivity of the chronic poor (Little et al., unpublished manuscript). This is where climate change adaptation intersects with wider development priorities.

As for improving communication, it is also time to rehabilitate the role of external facilitators and participants as useful contributors to the learning process, despite real dangers of tyrannical expert power. Their science input is essential for reabstracting analytical information and incorporating climate surprises as learning probes into scenario building. Including their knowledge can reduce biases toward local-level driving forces of change and false optimism in futures thinking. We advocate for more engaged teams of practitioners and researchers to design creative learning tools and means for clarifying climate facts and uncertainties. Who else is better positioned to translate and communicate complex dynamics, foster learning communities, challenge assumptions and empirical understandings, and maneuver between inquiry and action?

Without a doubt, committing to a learning process that aims to enhance anticipatory and adaptive capacity, especially among vulnerable populations, takes time and resources from both local stakeholders and external facilitators. It also requires a clear normative stance of what resilience means and for whom. Given the urgency and the scale of managing for resilience under climatic uncertainty, more climate knowledge in itself is not enough to make climate change adaptation work. This knowledge needs to be accessible for those who need it most, through carefully designed yet flexible, iterative learning-reflection that is tailored to real day-to-day risks, that allows experimentation in practice, and that offers tangible and short-term results. Learning by shock is neither an empowering nor an ethically defensible pathway.

Responses to this article can be read online at: http://www.ecologyandsociety.org/voll5/iss2/art11/ responses/

\section{Acknowledgments:}

We wish to thank the United States Agency for International Development (USAID) for supporting CCLONG (Climate Change Collective Learning and Observatory Network Ghana; \#EEMA-00-06-00014) and the National Science Foundation for funding HSD \#0826941 on anticipatory learning under climatic uncertainty in Ghana and Tanzania. We are gratefulfor conceptual contributions from Maureen Biermann, Robert Crane, Christopher Hoadley, Esther Prins, and Ken Tamminga and valuable input from Polly Ericksen, Emily Boyd, and Kamal Kapadia.

\section{LITERATURE CITED}

Adger, W. N. 2003. Social capital, collective action, and adaptation to climate change. Economic Geography 79(4):387-404.

Alexander Ballard Ltd. 2008. Adaptive capacity benchmarking: a handbook and toolkit. Project carried out for Hampshire County Council on behalf of the European Spatial Planning: Adapting to Climate Events (ESPACE) extension project, Berkshire, UK.

Argyris, C., and D. Schön. 1974. Theory in practice: increasing professional effectiveness. Jossey Bass, San Francisco, California, USA.

Argyris, C., and D. Schön. 1978. Organizational learning: a theory of action perspective. Addison Wesley, Reading, Massachusetts USA.

Argyris, C., and D. Schön. 1996. Organizational learning II: theory, method and practice. Addison Wesley, Reading, Massachusetts, USA.

Armitage, D. 2005. Adaptive capacity and community-based natural resource management. Environmental Management 35(6):703-715.

Armitage, D., M. Marschke, and R. Plummer. 2008. Adaptive co-management and the paradox of learning. Global Environmental Change 18:86-98. Wesley, Reading, MA, USA. 
Barrett, C. B. 2010. Poverty traps and resource dynamics in smallholder agrarian systems. Chapter 2 in A. Ruijs and R. Dellink, editors. Economics of poverty, environment and natural resource use. Springer, Dordrecht, The Netherlands.

Barrett, C. B., and J. G. McPeak. 2004. Poverty traps and safety nets. USAID Pastoral Risk Management (PARIMA) project, Cornell University, Ithaca, New York, USA. [online] URL: http://aem. cornell.edu/special_programs/AFSNRM/Parima/Papers/ BM povertytraps.pdf.

Barrett, C. B., T. Reardon, and P. Webb. 2001. Nonfarm income diversification and household livelihood strategies in rural Africa: concepts, dynamics and policy implications. Food Policy 26 (4):315-331.

Bebbington, A. 1999. Capitals and capabilities: a framework for analyzing peasant viability, rural livelihoods and poverty. World Development 27 (12):2012-2044.

Berkes, F. 2009. Evolution of co-management: role of knowledge generation, bridging

organizations and social learning. Journal of Environmental Management 90:1-11.

Berkes, F., J. Colding, and C. Folke, editors. 2003. Navigating social-ecological systems: building resilience for complexity and change. Cambridge University Press, Cambridge, UK.

Biggs, R., C. Raudsepp-Hearne, C. AtkinsonPalombo, E. Bohensky, E. Boyd, G. Cundill, H. Fox, S. Ingram, K. Kok, S. Spehar, M. Tengö, D. Timmer, and M. Zurek. 2007. Linking futures across scales: a dialog on multiscale scenarios. Ecology and Society 12 (1): 17. [online] URL: http ://www.ecologyandsociety.org/vol12/iss 1/art17/.

Bohensky, E. L. 2008. Discovering resilient pathways for South African water management: two frameworks for a vision. Ecology and Society $\mathbf{1 3}$ (1): 19. [online] URL: http://www.ecologyandsociety. org/vol13/iss 1/art19/.

Bohensky, E., and T. Lynam. 2005. Evaluating responses in complex adaptive systems: insights on water management from the Southern African Millennium Ecosystem Assessment (SAfMA). Ecology and Society. 10(1): 11. [online] URL: http ://www.ecologyandsociety.org/vol10/iss 1/art11.
Bradbury, H., and P. Reason. 2001. Conclusion: broadening the bandwidth of validity: issues and choice points for improving quality in action research. Pages 467-455 in P. Reason and $\mathrm{H}$. Bradbury, editors. Handbook of action research: participative inquiry and practice. Sage Publications, London, UK; Thousand Oaks, California, USA; and New Delhi, India.

Brockbank, W., and I. McGill. 1998. Facilitating reflective learning in higher education. Open University Press, Maidenhead, UK.

Brooks, N., and N. Grist. 2008. Development futures in the light of climate change: creating new insights into the past, the present and global futures. In Policy Forum: International Development in the face of Climate Change: Beyond Mainstreaming? Background paper for Development Futures Discussion. Department for International Development (DFID)/DSA Policy Forum, University of Greenwich, London, UK.

Carr, E. 2008. Between structure and agency: livelihoods and adaptation in Ghana's central region. Global Environmental Change 18:689-699.

Chandler, D., and B. Torbert. 2003. Transforming inquiry and action: interweaving 27 flavors of action research. Action Research 1(2):133-152.

Cohen, S., D. Neilson, S. Smith, T. Neale, B. Taylor, M. Barton, W. Merritt, Y. Alila, P. Shepherd, R. Mcneil, J. Tansey, J. Carmichael, and S. Langsdale. 2006. Learning with local help: expanding the dialogue on climate change and water management in the Okanagan Region, British Columbia, Canada. Climatic Change 75:331-358.

Cooke, B., and U. Kothari. 2001. Participation: the new tyranny? Zed Books, Ltd., New York, New York, USA.

Davidson-Hunt, I., and F. Berkes. 2003. Learning as you journey: Anishinaabe perception of socialecological environments and adaptive learning. Conservation Ecology 8(1): 5. [online] URL: http:/ /www.ecologyandsociety.org/vol8/iss1/art5.

Davies, S. 1996. Adaptable livelihoods: coping with food insecurity in the Malian Sahel. St. Martin's Press, Houndmills/Basingstoke, UK. 
Dick, B. 2002. Postgraduate programs using action research. The Learning Organization 9(4):159-170.

Ellis, F. 2000. Rural livelihoods and diversity in developing countries. Oxford University Press, Oxford, UK.

Ellis, F. 2003. A livelihoods approach to migration and poverty reduction. Paper commissioned by the Department for International Development (DFID), Norwich, UK.

Enfors, E. I., L. J. Gordon, G. D. Peterson, and D. Bossio. 2008. Making investments in dryland development work: participatory scenario planning in the Makanya Catchment, Tanzania. Ecology and Society 13 (2): 42. [online] URL: http://www.ecolo gyandsociety.org/vol13/iss2/art42.

Enne, G., and M. Yeroanni, editors. 2007. AIDCCD-Active exchange of experience on indicators and development of perspectives in the context of UNCCD: role of information circulation systems in scientific and practical approaches to combat desertification. Centro Interdipartimentale di Ateneo Nuclep Ricerca Desertificazione, Universita degli Studi di Sassari, Sassari, Italy.

Evans, K., S. J. Velarde, R. Prieto, S. N. Rao, S. Sertzen, K. Dávila, P. Cronkleton, and W. de Jong. 2006. Field guide to the future: four ways for communities to think ahead. Center for International Forestry Research (CIFOR), Jakarta, Indonesia; ASB and World Agroforestry Centre, Nairobi, Kenya. [online] URL: http://www.asb.cgiar.org/PD Fwebdocs/Evans-et-al-2006-Field-guide-to-the-future. pdf.

Fabricius, C., C. Folke, G. Cundill, and L. Schultz. 2007. Powerless spectators, coping actors, and adaptive co-managers: a synthesis of the role of communities in ecosystem management. Ecology and Society 12(1): 29. [online] URL: http://www.e cologyandsociety.org/vol12/iss 1/art29.

Finan, T. J., and D. R. Nelson. 2001. Making rain, making roads, making do: public and private adaptations to drought in Ceará, northeast Brazil. Climate Research 19:97-108.

Folke, C. 2006. Resilience: the emergence of a perspective for social-ecological systems analyses. Global Environmental Change 16(3):253-267.
Friedman, V. J. 2001. Action science: creating communities of inquiry in communities of practice. Pages 159-170 in P. Reason and H. Bradbury, editors. Handbook of action research: participative inquiry and practice. Sage Publications, London, UK; Thousand Oaks, California, USA; and New Delhi, India.

Füssel, H. M., and R. J. T. Klein. 2006. Climate change vulnerability assessments: an evolution of conceptual thinking. Climatic Change 75:310-329.

Greenwood, D., and M. Levin. 1998. An introduction to action research: social research for social change. Sage Publications, Thousand Oaks, California, USA.

Gunderson, L. H., and C. S. Holling, editors. 2002. Panarchy: understanding transformations in human and natural systems. Island Press, Washington, D.C., USA.

Hartanto, H., M. C. Lorenzo, C. Valmores, L. Arda-Minas, L. Burton, and A. Frio. 2003. Learning together: responding to change and complexity to improve community forests in the Philippines. CIFOR, Bogor, Indonesia.

Hellmuth, M. E., A Moorhead, M. C. Thomson, and J. Williams, editors. 2007. Climate risk management in Africa: learning from practice. International Research Institute for Climate and Society (IRI), Columbia University, New York, New York, USA.

Heron, J. 1992. Peeling and personhood: psychology in another key. Sage Publications, London, UK.

Holling, C. S. 1973. Resilience and stability of ecological systems. Annual Review of Ecology and Systematics 4:1-23.

Holling, C. S. 1986. The resilience of terrestrial ecosystems, local surprise and global change. Pages 292-317 in W. C. Clark and R. E. Munn, editors. Sustainable development of the biosphere. Cambridge University Press, Cambridge, UK.

Holling, C. S. 2004. From complex regions to complex worlds. Ecology and Society 9(1): 11. [online] URL: http://www.ecologyandsociety.org/vol9/ iss1/art11. 
Hulme, M., H. Neufeldt, H. Colyer, and A. Ritchie, editors. 2009. Adaptation and mitigation strategies: supporting European climate policy. The final report from the ADAM Project. Revised June 2009. Tyndall Centre for Climate Change Research, University of East Anglia, Norwich, UK.

Inayatullah, S. 2002. Questioning the future. Tamkang University Press, Tamsui, Taiwan.

Inayatullah, S. 2006. Anticipatory action learning: theory and practice. Futures 31:656-666.

Jäger, J., L. Bohunovsky, and J. Binder, editors. 2008. Methods and tools for integrated sustainability assessment. Project summary. Sustainable Europe Research Institute, Vienna, Austria.

Karkkainen, B. C. 2006. Panarchy and adaptive change: around the loop and back again. Minnesota Journal of Science and Technology 7(1): 59-77.

Keen, M., V. A. Brown, and R. Dyball. 2005. Social learning in environmental management: towards a sustainable future. Earthscan, London, UK.

Kelleher, A. 2005. A personal philosophy of anticipatory action-learning. Journal of Future Studies 10(1):85-90.

Kelly, P. M., and W. N. Adger. 2000. Theory and practice in assessing vulnerability to climate change and facilitating adaptation. Climatic Change 47:325-352.

Kesby, M. 2005. Retheorizing empowermentthrough-participation as a performance in space: beyond tyranny to transformation. Signs: Journal of Women in Culture and Society 30(4):2037-2065.

Kindon, S. 2005. Participatory action research. Pages 207-220 in I. Hay, editor. Qualitative research methods in human geography. Oxford University Press, New York, New York, USA.

Kok, K., R. Biggs, and M. Zurek. 2007. Methods for developing multiscale participatory scenarios: insights from southern Africa and Europe. Ecology and Society 13(1): 8. [online] URL: http://www.eco logyandsociety.org/vol12/iss1/art8/.
Kok, K., D. Rothman, S. Greeuw, and M. Patel. 2003. European scenarios: from VISIONS to MedAction: MedAction deliverable \# 2. Report number I03-E001. ICIS, Maastricht The Netherlands. [Online] URL: http://www.icis.unimaas.nl/medaction/ downs/Deliverable 2.pdf.

Kolb, D. A., and R. Fry. 1975. Toward an applied theory of experiential learning. Pages 33-57 in C. Cooper, editor. Theories of group process. Wiley, London, UK.

Leary, N., J. Adequwon, V. Barros, I. Burton, J. Kukarni, and R. Lasco, editors. 2008. Climate change and adaptation. Earthscan, London, UK.

Lebel, L., J. H. Anderies, B. Campbell, C. Folke, S. Hatfield-Dodds, T. P. Hughes, and J. Wilson. 2006. Governance and the capacity to manage resilience in regional social-ecological systems. Ecology and Society 11(1): 19. [online] ULR: http:// www.ecologyandsociety.org/vol11/iss1/art19

Lebel, L., P. Garden, and M. Imamura. 2005. The politics of scale, positions and place in the management of water resources in the Mekong region. Ecology and Society 10 (2): 18. [online] URL: http://www.ecologyandsociety.org/vol10/iss2/ $\underline{\operatorname{art18} .}$

Lefebvre, H. 1991. The production of space. Blackwell, Oxford, UK.

Lemos, M. C., E. Boyd, E. L. Tompkins, H. Osbahr, and D. Liverman. 2007. Developing adaptation and adapting development. Ecology and Society 12(2): 26. [online] URL: http://www.ecolog yandsociety.org/vol12/iss2/art26/.

Lewin, K. 1946. Action research and minority problems. Journal of Social Issues 2:34-46.

List, D. 2006. Action research cycles for multiple futures perspectives. Futures 38:673-684.

Little P. D., K. Smith, B. A. Cellarius, D. L. Coppock, and C. Barrett. 2001. Avoiding disaster: diversification and risk management among East African herders. Development and Change 32:401433.

Liverman, D. M. 2008. Conventions of CC: constructions of danger and dispossession of the 
atmosphere. Journal of Historical Geography 35:279-296.

Lonsdale, K. 2009a. A background to learning example approach. ADAM digital compendium, adaptation and mitigation strategies: supporting European climate policy (ADAM).

[online] URL: http://adam-digital-compendium.pikpotsdam.de/learning-examples/background.

Lonsdale, K. 2009b. How to do networks and "communities of practice" support the process of getting action on adaptation? ADAM digital compendium, adaptation and mitigation strategies: supporting European climate policy (ADAM). [online] URL: http://adam-digital-compendium.pikpotsdam.de/learning-examples/lessons-learned/adaptationnetworks/.

Lynam, T., F. Bousquet, C. LePage, P. d'Aquino, O. Barreteau, F. Chinembiri, and B. Mombeshora. 2002. Adapting science to adaptive managers: spidergrams, belief models, and multiagent systems modeling. Conservation Ecology 5 (2): 24. [online] URL: http://www.ecologyandsociety. org/vol5/iss2/art24/.

Maguire, P. 1987. Doing participatory research: a feminist approach. The Center for International Education, School of Education, University of Massachusetts, Amherst, Massachusetts, USA.

Marx, S. M., E. U. Weber, B. S. Orlove, A. Leiserowitz, D. H. Krantz, C. Roncoli, and J. Phillips. 2007. Communication and mental processes: experiential and analytic processing of uncertain climate information. Global Environmental Change 17:47-58.

McGray, H., A. Hammill, R. Bradley with E. L. Schipper, and J.-E. Parry. 2007. Weathering the storm: options for framing adaptation and development. World Resource Institute Report, Washington, D.C., USA.

McTaggart, R. 1991. Principles of participatory action research. Adult Education Quarterly $\mathbf{4 3}$ (3):168-187.

Mortimore, M., and W. M. Adams. 1999. Working the Sahel: environment and society in northern Nigeria. Routledge, London, UK.
Nelson, D. R., W. N. Adger, and K. Brown. 2007. Adaptation to environmental change: contributions of a resilience framework. Annual Review of Environment and Resources 32:395-419.

Nelson, D. R., and T.J. Finan. 2009. Weak winters: dynamic decision making in the face of extended drought in Ceará, Brazil. Pages 117-132 in E. C. Jones and A. D. Murphy, editors. The political economy of hazards and disasters. AltaMira, Walnut Creek, California, USA.

Ochola, W., M. Cheje,A.Abdelrehim, P. J.Ayugi, B. Ayeni, J. Asamoah, E. Gowa, and J. Roberts. 2006. The future today. Pages 412-477 in J. C. Mohamed-Katerere and M. Sabet, editors. Africa environment outlook 2: our environment, our wealth. United Nations Environment Programme, Nairobi, Kenya.

Olsson, P., C. Folke, and T. Hahn. 2004. Socialecological transformation for ecosystem management: the development of adaptive co-management of a wetland landscape in southern Sweden. Ecology and Society 9(4): 2. [online] URL: http://www.ecol ogyandsociety.org/vol9/iss4/art2.

Olsson, P., L. H. Gunderson, S. R. Carpenter, P. Ryan, L. Lebel, C. Folke, and C. S. Holling. 2006. Shooting the rapids: navigating transitions to adaptive governance of social-ecological systems. Ecology and Society 11(1): 18. [online] URL: http: //www.ecologyandsociety.org/vol11/iss1/art18/.

Osbahr, H. 2007. Building resilience: adaptation mechanisms and mainstreaming for the poor. Fighting climate change: human solidarity in a divided world. Background paper for UNDP Human Development Report 2007/2008, New York, New York, USA.

Osbahr, H., with E. Boyd and P. Ericksen. 2007. Resilience, realities and research in African environments. Report of workshop 18 June 2007. University of Oxford, Oxford, UK.

Pain, R. 2003. Social geography: on action-oriented research. Progress in Human Geography 27 (5):649-657.

Park, P., M. Brydon-Miller, B. Hall, and T. Jackson, editors. 1993. Voices of change: participatory research in the United States and 
Canada. Bergin and Garvey, Westport, Connecticut, USA.

Patel, M., K. Kok, and D. S. Rothman. 2007. Participatory scenario construction in land use analysis: an insight into the experiences created by stakeholder involvement in the northern Mediterranean. Land Use Policy 24:546-561.

Pelling, M., and C. High. 2005. Social learning and adaptation to climate change. Disaster Studies Working Paper 11, Benfield Hazard Research Centre, London, UK.

Peterson, G. D. 2007. Using scenario planning to enable an adaptive co-management process in the Northern Highlands Lake District of Wisconsin. Pages 289-307 in D. Armitage, F. Berkes, and N. Doubleday, editors. Adaptive co-management: collaboration, learning, and multi-level governance. University of British Columbia Press, Vancouver, British Columbia, Canada.

Reason, P., and H. Bradbury, editors. 2001. Handbook of action research: participative inquiry and practice. Sage Publications, London, UK.

Reason, P., and W. R. Torbert. 2001. The action turn: toward a transformational social science. Concepts and Transformations 6(1):1-37.

Ramos, J. M. 2006a. Action research and futures studies Futures 31:639-641.

Ramos, J. M. 2006b. Dimensions in the confluences of futures studies and action research. Futures 38:642-655.

Red Cross/ Red Crescent. 2007. Climate guide. International Federation of Red Cross and Red Crescent Societies, Netherlands Red Cross, The Hague, The Netherlands.

Scoones, I. 1998. Sustainable rural livelihoods: a framework for analysis. IDS Working Paper No. 72. IDS University of Sussex, Brighton, UK.

Schipper, E. L. F. 2007. Climate change adaptation and development: exploring the linkages. Working Paper 107, Tyndall Centre for Climate Change Research, Norwich, UK.

Seely, M., E. Dirkx, C. Hager, P. Klintenberg, C. Roberts and D. von Oertzen. 2008. Advances in desertification and $\mathrm{CC}$ research: are they accessible for application to enhance AC? Global and Planetary Change 64(3-4):236-243.

Smit, B., and J. Wandel. 2006. Adaptation, adaptive capacity and vulnerability. Global Environmental Change 16:282-292.

Smith, K., C. Barrett, and P. Box. 2000. Participatory risk mapping for targeting research and assistance: with an example from east African pastoralists. World Development 28(1):1945-1959.

Stevenson, T. 2002. Anticipatory action learning: conversations about the future. Futures 34:417425.

Stevenson, T. 2006. From vision to action. Futures 38:667-672.

Swart, R. J., P. Raskin, J. Robinson, R. Kates, and W. C. Clark. 2004. The problem of the future: sustainability science and scenario analysis. Global Environmental Change 14(2):137-146.

Thomas, D. S. G., and C. Twyman. 2005. Equity and justice in climate change adaptation amongst natural-resource-dependent societies. Global Environmental Change Part A 15(2):115-124.

Tompkins, E. L., R. Few, and K. Brown. 2008. Scenario-based stakeholder engagement: incorporating stakeholders preferences into coastal planning for climate change. Journal of Environmental Management 88:1580-1592.

Torbert, W. 1983. Research cultivation executive mind, timely action. ReVision 4:1-23.

Torbert, W. 1991. The power of balance: transforming self, society, and scientific inquiry. Sage Publications, Newbury Park, California, USA.

Tschakert, P. 2007. Views from the vulnerable: understanding climatic and other stressors in the Sahel. Global Environmental Change 7:381-396.

Twomlow, S., F. T. Mugabe, M. Mwale, R. Delve, D. Nanja, P. Carberry, and M. Howden. 2008. Building adaptive capacity to cope with increasing vulnerability due to climatic change in Africa-a new approach. Physics and Chemistry of the Earth 33:780-787. 
van Aalst, M. K., T. Cannon, and I. Burton. 2008. Community level adaptation to climate change: the potential role of participatory community risk assessment. Global Environmental Change 18:165179.

Walker, B., S. Carpenter, J. Anderies, N. Abel, G. S. Cumming, M. Janssen, L. Lebel, J. Norberg, G. D. Peterson, and R. Pritchard. 2002. Resilience management in social-ecological systems: a working hypothesis for a participatory approach. Conservation Ecology 6(1): 14. [online] URL: http://www.consecol.org/vol6/iss 1/art14/.

Walker, B. H., L. H. Gunderson, A. P. Kinzig, C. Folke, S. R. Carpenter, and L. Schultz. 2006. A handful of heuristics and some propositions for understanding resilience in social-ecological systems. Ecology and Society 11(1): 13. [online] URL: http://www.ecologyandsociety.org/vol11/iss1/ $\underline{\operatorname{art13/}}$.

Wollenberg, E., D. Edmunds, and L. Buck. 2000. Using scenarios to make decisions about the future: anticipatory learning for the adaptive comanagement of community forests. Landscape and Urban Planning 47:65-77.

Wollenberg, E., R. Iwan, G. Limberg, M. Moeliono, S. Rhee, and M. Sudana. 2007. Facilitating cooperation during times of chaos: spontaneous orders and muddling through in Malinau District, Indonesia. Ecology and Society 12(1): 3. [online] URL: http://www.ecologyandsoc iety.org/vol12/iss 1/art3. 